\section{Placental transfer of lidocaine hydrochloride after prolonged continuous maternal intravenous administration}

Michio Banzai MD, Satoshi Sato MD,

Naohiro Tezuka MD, Hiromi Komiya MD,

Tetsuro Chimura MD, Masahiko Hiroi MD
We treated a patient with arrhythmia during pregnancy with prolonged intravenous administration of lidocaine hydrochloride. This was a case of twin-to-twin transfusion syndrome and the arrhythmia was caused by ritodrine therapy. In total, 14.1 $\mathrm{g}$ lidocaine (50 mg $\cdot \mathrm{hr}^{-1}$ for $282 \mathrm{hr}$ ) were used. Since there are no descriptions of human placental transfer of lidocaine after such a prolonged continuous intravenous administration, we measured lidocaine concentrations in maternal and fetal serum, and in the amniotic fluid $(A F)$ at delivery. Fetal serum lidocaine concentrations (donor: $0.83 \mu \mathrm{g} \cdot \mathrm{ml}^{-1}$; recipient: $0.82 \mu \mathrm{g} \cdot \mathrm{ml}^{-1}$ ) were lower than in the maternal serum $\left(1.6 \mu \mathrm{g} \cdot \mathrm{ml}^{-1}\right)$, while the AF lidocaine concentrations (donor: $1.05 \mu \mathrm{g} \cdot \mathrm{ml}^{-1}$; recipient: $1.04 \mu \mathrm{g} \cdot \mathrm{ml}^{-1}$ ) were higher than those of the fetal sera. The fetal/maternal concentration ratios of lidocaine were 0.52 for the donor and 0.51 for the recipient, which were similar to those described previously after administration of lidocaine in labour.

Nous avons traité l'àrythmie d'une parturiente porteuse de jumeaux avec de lhydrochlorure lidocaïne iv. Il sagissait d'un syndrome de gémellité perfuseur-perfusé et l'arythmie était consécutive au traitement à la ritodrine. En tout, $14,1 \mathrm{~g}$ (50

\section{Key words}

ANAESTHESIA: obstetric;

ANAESTHETICS, LOCAL: lidocaine;

UTERUS: tocolytics, ritodrine;

COMPLICATION: arrhythmia;

PHARMACOKINETICS: placental transfer, serum

concentration;

PLACENTA: drug transfer.

From the Department of Obstetrics and Gynecology,

Yamagata University School of Medicine, Yamagata, Japan.

Address correspondence to: Dr. Michio Banzai, Department of Obstetrics and Gynecology, Yamagata University School of Medicine, 2-2-2 Iida-Nishi, Yamagata 990-23, Japan.

Accepted for publication 18th December, 1994. $m g \cdot h^{-1}$ pour $282 h$ ) de lidocaïne ont été administrées. Comme on n'a jamais rapporté de données sur le transfert placentaire de la lidocaïne après une administration iv aussi prolongée, nous avons mesuré à l'accouchement les concentrations sériques maternelles et foetales de lidocaïne, et la concentration sérique de liquide amniotique ( $L A)$ de lidocä̈ne. Les concentrations sériques (perfuseur: 0,83 $\mathrm{\mu g} \cdot \mathrm{ml}^{-1}$; perfusé: $0,82 \mu \mathrm{g} \cdot \mathrm{ml}^{-1}$ ) étaient moins élevées que dans le sérum maternel (1,6 $\mu \mathrm{g} \cdot \mathrm{ml}^{-1}$ ), alors que dans le $\mathrm{LA}$ (perfuseur: $1,05 \mu \mathrm{g} \cdot \mathrm{ml}^{-1}$, perfusé; $1.04 \mu \mathrm{g} \cdot \mathrm{ml}^{-1}$ ) les concentrations étaient plus élevées que dans le sérum foetal. Les rapports concentration foetus/ mère de lidocaïne étaient de 0,52 pour le perfuseur et de 0,51 pour le perfusé et identiques à ceux trouvés après l'administration de lidocaïne pendant le travail.

Lidocaine is widely used for maternal analgesia during labour and sometimes for the treatment of arrhythmia in pregnant women. There are many reports of human placental lidocaine transfer after brief administration following maternal epidural, spinal, caudal, paracervical or pudendal analgesia during labour. However, for continuous maternal lidocaine infusion, several studies have been reported but only in animals. ${ }^{1-3}$ There are no reports on the effects in humans of continuous maternal intravenous lidocaine administration on fetal serum and amniotic fluid (AF) lidocaine concentrations. Since it is possible for excessive fetal serum and AF lidocaine concentrations to be produced in humans, we submit this report on a patient who received intravenous administration of lidocaine hydrochloride for 12 days to treat arrhythmia during pregnancy. Maternal serum, fetal serum and $\mathrm{AF}$ lidocaine concentrations were measured at the time of delivery.

\section{Case report}

A 30-yr-old woman was referred at 23 wk gestation because of preterm labour and polyhydramnios. She was 
TABLE Matemal and fetal lidocaine concentrations

\begin{tabular}{|c|c|c|c|c|c|}
\hline & \multirow[b]{2}{*}{ Maternal vein } & \multicolumn{4}{|c|}{ Lidocaine concentration $\left(\mu \mathrm{g} \cdot \mathrm{ml}^{-1}\right)$} \\
\hline & & Umbilical vein & Umbilical artery & Amniotic fluid & $\begin{array}{l}\text { Umbilical vein/ } \\
\text { maternal vein ratio }\end{array}$ \\
\hline Present case & 1.6 & & & & \\
\hline - donor twin & & 0.83 & & 1.05 & 0.52 \\
\hline - recipient twin & & 0.82 & & 1.04 & 0.51 \\
\hline Guay et $a l^{4}$ & 8.04 & 3.92 & & & 0.54 \\
\hline Loftus et al. ${ }^{5}$ & 2.61 & 1.17 & 0.79 & & 0.48 \\
\hline Kileff $e t a l^{6}$ & 2.65 & 1.82 & 1.19 & & 0.69 \\
\hline Abboud et $a l^{7}$ & 2.4 & 1.27 & 1.16 & & 0.48 \\
\hline Abboud et $a l^{8}$ & 1.98 & 1.25 & 0.91 & & 0.66 \\
\hline Abboud et al. ${ }^{9}$ & 3.10 & 1.43 & 1.23 & & 0.48 \\
\hline
\end{tabular}

diagnosed clinically as a case of twin-to-twin transfusion syndrome on the basis of ultrasonographic criteria, ${ }^{4}$ which showed a monochorionic placenta, discordancy of growth with fetuses of the same sex, oligohydramnios in the sac of the donor and polyhydramnios in that of the recipient. Our regimen for preterm labour included bed rest and the infusion of ritodrine (maximum dosage: $\left.300 \mu \mathrm{g} \cdot \mathrm{min}^{-1}\right)$. Ritodrine therapy had also been performed two days before referral to our department. Ritodrine had been infused at a dosage of $50 \mu \mathrm{g} \cdot \mathrm{min}^{-1}$ at first and increased to $200 \mu \mathrm{g} \cdot \mathrm{min}^{-1}$ to prevent preterm labour. We restarted the infusion of ritodrine at a dosage of $190 \mu \mathrm{g} \cdot \min ^{-1}$ and maintained this dosage throughout. After the administration of ritodrine had been started, occasional premature ventricular contractions (PVC) were seen on the ECG monitor, and were suspected to be a side effect of ritodrine. ${ }^{5}$ Twelve days after the start of our treatment, the frequency of PVCs increased. Since ritodrine therapy was effective for the prevention of preterm labour, we decided to continue this while also using lidocaine hydrochloride to prevent PVCs. The dosage of ritodrine was not reduced, nor was any other tocolytic agent used. Lidocaine hydrochloride was administered at $50 \mathrm{mg} \cdot \mathrm{hr}^{-1} \dot{i v}$ throughout. The frequency of PVC decreased, while decompression amniocentesis was performed to relieve maternal discomfort, respiratory embarrassment and preterm labour. However, serial ultrasonographic examination continued to show the development of acute polyhydramnios and hydrops of the recipient twin.

It was decided to terminate pregnancy and the administration of ritodrine was discontinued four hours before the operation. A Caesarean section was performed at 27 wk gestation. A $960 \mathrm{~g}$ girl (donor twin) and a 1450 $\mathrm{g}$ girl (recipient twin) were born living but in poor condition with Apgar scores of 1 and 2 respectively. The gastric contents of each neonate were aspirated. Their tracheas intubated and their lungs ventilated to relieve respiratory insufficiency. Samples of AF were aspirated at the time of rupture of the membranes and, at delivery, blood samples were drawn from the maternal vein as well as from the umbilical vein in a double-clamped segment of the umbilical cords. After the operation, the administration of lidocaine was discontinued. Because of respiratory distress and intracranial haemorrhage, the donor twin died at 12 , and the recipient twin at 16 days of age.

In total, $14.1 \mathrm{~g}$ lidocaine $\left(50 \mathrm{mg} \cdot \mathrm{kg}^{-1} \cdot \mathrm{hr}^{-1}\right.$ for 282 hr) had been administered to the mother. Serum and AF concentrations of lidocaine were measured with a fluorescence polarization immunoassay (Dainabot Laboratories, Tokyo, Japan). This immunoassay method reportedly produces superior correlation $(r=0.998)$ than high-resolution gas chromatography. ${ }^{6}$ Maternal serum, fetal serm and AF lidocaine concentrations, as well as the fetal/maternal concentration ratios of lidocaine are shown in the Table and compared with previously reported studies.

\section{Discussion}

Local anaesthetics rapidly cross the placenta through passive diffusion. The placental transfer of basic drugs by passive diffusion is governed largely by their molecular weight, lipid solubility, $\mathrm{pKa}$ and protein binding. Thus, a base such as lidocaine (molecular weight $=234$; oilwater distribution ratio at $\mathrm{pH} 7.20=30.2 ; \mathrm{pKa}=7.86$ ) crosses the placenta easily and rapidly. ${ }^{?}$

In our patient, fetal and maternal serum lidocaine concentrations were lower than those reported previously when lidocaine was used for maternal epidural analgesia during labour. However, the fetal/maternal concentration ratios of lidocaine were similar ${ }^{8-13}$ (Table). Because of the limitation of fetal/maternal transfer of lidocaine, fetal serum concentrations may not increase unless maternal serum concentrations increase notably. In our case, AF lidocaine concentrations were higher than lidocaine con- 
centrations in the fetal serum. We had assumed that accumulation of lidocaine tends to occur in the AF, but AF lidocaine concentrations did not increase even after such prolonged administration.

While fetal hypoxia and acidosis increase blood flow to the brain and to the heart to improve oxygen transport, these circulatory adaptations to asphyxia also increase the transfer of lidocaine across the placenta. In addition, fetal acidosis causes accumulation of lidocaine in fetal blood. ${ }^{7}$ The gastric juice in the fetus may then become more acidic because of fetal distress, so that lidocaine can cross the fetal lipid gastric barrier and dissociate according to the gastric $\mathrm{pH}$. Gastric fluid lidocaine concentrations have been reported to be higher than fetal serum concentrations. ${ }^{14}$ The AF lidocaine concentrations were also higher than fetal serum concentrations in our patient. Since the fetus may swallow AF at various stages of pregnancy, gastric washout of the neonates may be effective in reducing the fetal serum concentration after delivery when neonatal intoxication with lidocaine is suspected, especially in cases of fetal distress.

Scanlon et al. ${ }^{15}$ reported that lidocaine compromises neonatal neurobehavioural function when used for epidural analgesia during labour and vaginal delivery. Recently, however, numerous reports attest to the fetal and neonatal safety of maternal obstetrical anaesthesia with lidocaine ${ }^{8-13}$ However, administration of a large dose of lidocaine may produce excessive fetal and neonatal serum concentrations, leading to central nervous and cardiovascular system toxicity manifested as convulsions, reduced Apgar scores, marked bradycardia, cyanosis, apnoea and unresponsiveness to positive-pressure ventilation with oxygen.

The polyhydramnios and preterm labour in our case, could not be improved but ritodrine therapy was effective in controlling uterine contraction. Therefore, it was decided to continue infusion of ritodrine while using lidocaine hydrochloride to prevent PVCs. We did not monitor maternal lidocaine concentrations but, on the basis of this experience, we assume that careful monitoring of maternal lidocaine concentrations may be beneficial to reduce or eliminate the risk of fetal morbidity.

\section{References}

1 Pedersen H, Santos AC, Morishima HO, et al. Does gestational age affect the pharmacokinetics and pharmacodynamics of lidocaine in mother and fetus? Anesthesiology 1988; 68: 367-72.

2 Kennedy RL, Bell JU, Miller RP, et al. Uptake and distribution of lidocaine in fetal lambs. Anesthesiology 1990; 72: 483-9.

3 Smedstad KG, Morison DH, Harris WH, Pascoe P. Placental transfer of local anaesthetics in the premature sheep fetus. International Journal of Obstetric Anesthesia 1993; 2: 34-8.

4 Benedetti TJ. Maternal complications of parenteral $\beta$ sympathomimetic therapy for premature labor. Am $\mathbf{J}$ Obstet Gynecol 1983; 145: 1-6.

5 Winn HN, Gabrielli S, Reece EA, Roberts JA, Salafia C, Hobbins $J C$. Ultrasonographic criteria for the prenatal diagnosis of placental chorionicity in twin gestations. Am J Obstet Gynecol 1989; 161: 1540-2.

6 Bertol E, Mari F, Torracca F. Comparison of lidocaine by fluorescence polarization immunoassay, enzyme immunoassay, and high resolution gas chromatography. J Anal Toxicol 1987; 11: 122-6.

7 Ralston DH, Shnider SM. The fetal and neonatal effects of regional anesthesia in obstetrics. Anesthesiology 1978; 48: 34-64.

8 Guay J, Gaudreault P, Boulanger A, Tang A, Lortie L, Dupuis $C$. Lidocaine hydrocarbonate and lidocaine hydrochloride for cesarean section: transplacental passage and neonatal effects. Acta Anaesthesiol Scand 1992; 36: 722-7.

9 Lofius JR, Holbrook RH, Cohen SE. Fetal heart rate after epidural lidocaine and bupivacaine for elective cesarean section. Anesthesiology 1991; 75: 406-12.

10 Kileff ME, James FM III, Dewan DM, Floyd HM. Neonatal neurobehavioral responses after epidural anesthesia for cesarean section using lidocaine and bupivacaine. Anesth Analg 1984; 63: 413-7.

11 Abboud TK, Afrasiabi A, Sarkis F, et al. Continuous infusion epidural analgesia in parturients receiving bupivacaine, chloroprocaine, or lidocaine - maternal, fetal, and neonatal effects. Anesth Analg 1984; 63: 421-8.

12 Abboud TK, Sarkis F, Blikian A, Varakian L, Earl S, Henriksen $E$. Lack of adverse neonatal neurobehavioral effects of lidocaine. Anesth Analg 1983; 62: 473-5.

13 Abboud TK, Kim KC, Noueihed $R$, et al. Epidural bupivacaine, chloroprocaine, or lidocaine for cesarean section maternal and neonatal effects. Anesth Analg 1983; 62: 914-9.

14 Datta S, Houle GL, Fox GS. Concentration of lidocaine hydrochloride in newborn gastric fluid after elective Caesarean section and vaginal delivery with epidural analgesia. Can Anaesth Soc J 1975; 22: 79-83.

15 Scanlon JW, Brown WU, Weiss JB, Alper $M H$. Neurobehavioral responses of newborn infants after maternal epidural anesthesia. Anesthesiology 1974; 40: 121-8. 